\title{
Endocrine Regulation of the Growth Plate
}

\author{
Ola Nilsson $^{a}$ Rose Marino ${ }^{a}$ Francesco De Luca $^{b}$ Moshe Phillip ${ }^{c}$ \\ Jeffrey Baron ${ }^{a}$ \\ ${ }^{a}$ Developmental Endocrinology Branch, National Institute of Child Health and Human Development, National \\ Institutes of Health, Bethesda, Md., and 'bection of Endocrinology and Diabetes, St. Christopher's Hospital \\ for Children, Philadelphia, Pa., USA; ' Institute for Endocrinology and Diabetes, Schneider Children's Medical \\ Center of Israel, Petah Tikva, Israel
}

\section{Key Words}

Hormones $\cdot$ Growth plate $\cdot$ Longitudinal bone growth .

Growth hormone - Insulin-like growth factor -

Glucocorticoid · Thyroid hormone · Estrogen •

Androgen $\cdot$ Vitamin D $\cdot$ Leptin

\begin{abstract}
Longitudinal bone growth occurs at the growth plate by endochondral ossification. Within the growth plate, chondrocyte proliferation, hypertrophy, and cartilage matrix secretion result in chondrogenesis. The newly formed cartilage is invaded by blood vessels and bone cells that remodel the newly formed cartilage into bone tissue. This process of longitudinal bone growth is governed by a complex network of endocrine signals, including growth hormone, insulin-like growth factor I, glucocorticoid, thyroid hormone, estrogen, androgen, vitamin $D$, and leptin. Many of these signals regulate growth plate function, both by acting locally on growth plate chondrocytes and also indirectly by modulating other endocrine signals in the network. Some of the local effects of hormones are mediated by changes in paracrine factors that control chondrocyte proliferation and differentiation. Many human skeletal growth disorders are caused by abnormalities in the endocrine regulation of the growth plate. This review provides an overview of
\end{abstract}

the endocrine signals that regulate longitudinal bone growth, their interactions, and the mechanisms by which they affect growth plate chondrogenesis.

Copyright (c) 2005 S. Karger AG, Basel

\section{Introduction}

Longitudinal bone growth occurs at the growth plate by a process called endochondral ossification in which cartilage is first formed and then remodeled into bone tissue. The growth plate consists of three principal layers: the resting zone, proliferative zone, and hypertrophic zone (fig. 1). Chondrocyte proliferation, hypertrophy, and extracellular matrix secretion result in chondrogenesis. The newly formed cartilage is invaded by blood vessels and bone cell precursors, which remodel the hypertrophic zone cartilage into bone. The net effect is that new bone tissue is progressively created at the bottom of the growth plate, resulting in bone elongation.

The growth plate contains one cell type, the chondrocyte, at different stages of differentiation. Resting zone chondrocytes replicate at a slow rate [1] and act as the stem-like cells that replenish the pool of proliferative chondrocytes [2]. Proliferative zone chondrocytes replicate at a high rate [1], and the resulting daughter cells line up along the long axis of the bone. As a result, clones of

\section{KARGER}

(c) 2005 S. Karger AG, Basel

Fax +41613061234

E-Mail karger@karger.ch

www.karger.com www.karger.com/hre
Ola Nilsson

National Institutes of Health, NICHD

Building 10, Room 10N262, 10 Center Dr. MSC 1862

Bethesda, MD 20892-1862 (USA)

Tel. +1 301402 7265, Fax +1 301496 7914, E-Mail ola.nilsson@nih.gov 
Fig. 1. Histology of the growth plate. The growth plate is a thin cartilage structure situated in the ends of tubular bones. It is commonly subdivided into three distinct zones; the resting, proliferative, and hypertrophic zones.

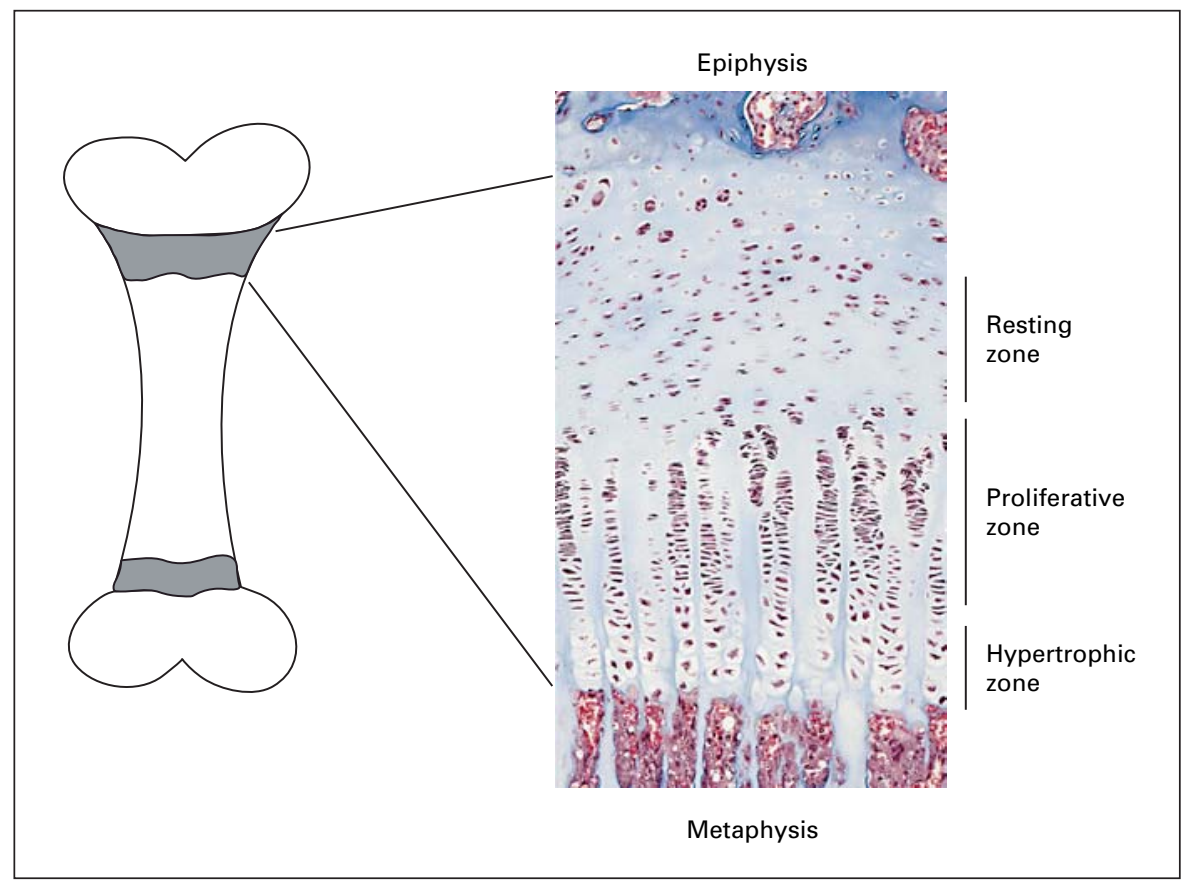

chondrocytes are arranged in columns parallel to this axis, a process critical to the formation of bones with an elongated shape [2].

At a certain point, the cells stop dividing and terminally differentiate into hypertrophic chondrocytes [1]. During the hypertrophic process, chondrocytes increase their height about 6- to 10-fold, and thus hypertrophic differentiation makes an important contribution to longitudinal growth [3]. The hypertrophic chondrocytes calcify the surrounding extracellular matrix and produce factors that attract the invading bone cells and blood vessels, including vascular endothelial growth factor [4]. Hypertrophic chondrocytes undergo apoptosis shortly before the blood vessels invade the chondrocyte lacuna [5].

\section{Basic Principles of Growth Plate Physiology}

The rate of growth plate chondrocyte proliferation, and hence the rate of longitudinal bone growth, falls progressively with age [1]. That decrease in growth plate function appears to be due to a mechanism intrinsic to the growth plate rather than a hormonal or other systemic mechanism; in growth plate transplantation experiments, the growth rate of the transplanted growth plate depends on the age of the donor animal, not the age of the recipient [6]. The term growth plate senescence [7] has been used to describe this intrinsic process that involves both a decline in the function and cellularity of the growth plate. Recent evidence suggests that this decline occurs because stem-like cells in the resting zone have a finite proliferative capacity that is gradually exhausted [8, 9]. In some mammals, including humans, the growth plate cartilage is completely replaced by bone at the time of sexual maturation. This event, termed epiphyseal fusion, appears to be triggered when the proliferative capacity of the growth plate chondrocytes is finally exhausted $[8,9]$.

Longitudinal bone growth is tightly governed by complex endocrine controls such that optimal growth occurs only in a healthy, well-nourished individual. If the individual is ill or malnourished, insulin-like growth factor (IGF)-I levels decline, glucocorticoid levels may rise, and thyroid hormone levels may decline causing linear growth to slow. Thus, one of the teleological reasons for the endocrine regulation may be to conserve nutrients for vital functions during times of adversity. At such times growth may be an unaffordable luxury that must be postponed until better times. Indeed, when this occurs, growth is primarily delayed and not lost irreversibly.

Our understanding in this field is derived primarily from two sources. First, human diseases involving hormone deficiency, hormone resistance, and hormone excess have provided great insight into the physiological 
role of hormones in human skeletal growth. Second, animal studies, including gland ablation, hormone administration, and molecular ablation or overexpression of specific endocrine-related genes, have also provided insights. However, findings in other mammals may not apply directly to humans. For example, the stimulatory effects of estrogen on skeletal growth and maturation, which occur in humans, are poorly reproduced in rodent studies.

\section{Growth Hormone and Insulin-Like Growth Factors}

Growth hormone $(\mathrm{GH})$ and insulin-like growth factors (IGFs) are potent stimulators of longitudinal bone growth. GH excess, due to pituitary adenomas in childhood, results in gigantism. Conversely, GH deficiency or insensitivity due to GH-receptor mutations or defects in $\mathrm{GH}$ signaling pathways markedly impairs postnatal growth [10-12]. Final height data on patients with untreated isolated GH deficiency suggests that it leads to an average final height SDS of -4.7 (-6.1 to -3.9) [12]. GH deficiency and insensitivity do not impair prenatal growth significantly. In contrast, both pre- and postnatal growth deficits occurred in the only reported cases of IGF-I deficiency due to a mutation in the igf- 1 gene [13] and of IGF-I resistance due to mutations in the type I IGF receptor gene [14].

The role of the GH-IGF axis in longitudinal bone growth has been evaluated by genetic targeting of its components in mice. Mice lacking the GH gene exhibit normal birth weight, but a reduction in postnatal growth [15]. Mice lacking either the igf- 1 or $i g f-2$ genes show intrauterine growth retardation with birth weights approximately $60 \%$ that of wild-type littermates [16]. Mice deficient in the IGF-I receptor have even more severe reduction in birth weight ( $45 \%$ of wild type) and die soon after birth due to respiratory failure [16].

The original somatomedin hypothesis stipulates that the effect of GH on linear growth is mediated by liverderived IGF-I [17]. The role of circulating IGF-I has been evaluated recently using tissue-specific gene targeting. Liver-specific ablation of igf- 1 in mice using the cre-lox system reduces circulating IGF-I levels by approximately $80 \%$, but has no appreciable effect on postnatal growth. However, in these mice, changes in IGF-binding proteins may have preserved bioactive IGF-I levels [18]. Combined deficiency of liver-derived IGF-I and knock-out of acid-labile substance (a component of the circulating IGF-I complex) further reduces circulating IGF-I levels and does inhibit linear growth and growth plate height [19]. In addition, in both mice and humans with inactivating mutations in the $\mathrm{GH}$ receptor, increased circulating IGF-I can markedly improve linear bone growth, supporting a role for circulating IGF-I [20, 21].

$\mathrm{GH}$ can also stimulate longitudinal bone growth by a local action on the growth plate. Injection of GH into the tibial growth plate accelerates longitudinal growth in the injected growth plate compared to the vehicle-injected contralateral growth plate [22]. Part of the local action of $\mathrm{GH}$ on the growth plate may be mediated by increased local production of IGF-I, which then acts in a paracrine/ autocrine fashion to increase chondrogenesis [23, 24]. In addition, GH may also have an effect on the growth plate that is independent of both endocrine and paracrine IGFI. The dual effector hypothesis states that $\mathrm{GH}$ acts locally at the growth plate to recruit resting chondrocytes into a proliferative state [25], as well as to stimulate local IGFI production, which then stimulates proliferation of proliferative zone chondrocytes [24-26]. However, detailed in vivo labeling experiments suggest that IGF-I, like GH, can stimulate proliferation of resting zone chondrocytes and chondrocyte hypertrophy [27]. In contrast, studies in IGF-I-deficient mice suggest that IGF-I acts primarily to increase hypertrophic cell height, with little effect on proliferation [28].

\section{Glucocorticoid}

Glucocorticoids are widely used as anti-inflammatory and immunosuppressive drugs in children. Long-term, high-dose glucocorticoid treatment often leads to growth failure. Similarly, systemic administration of glucocorticoid in mice, rats, and rabbits decreases the rate of longitudinal bone growth, by inhibiting growth plate chondrocyte proliferation $[8,29]$. In addition, glucocorticoid may stimulate apoptosis of growth plate chondrocytes $[29,30]$.

Glucocorticoid inhibits longitudinal bone growth, in part, through a direct effect on growth plate chondrocytes. Glucocorticoid receptor is expressed by growth plate chondrocytes [29]. Furthermore, glucocorticoid inhibits proliferation of growth plate chondrocytes in vitro [31]. In addition, local infusion of dexamethasone into the growth plate causes a local inhibition of longitudinal bone growth [32].

The local effects of glucocorticoid on growth plate chondrocyte proliferation may be mediated, in part, by changes in the local IGF-I system. Short-term systemic 
administration of glucocorticoid in rodents decreases IGF-I expression in the growth plate [33]. In contrast, long-term treatment of rodents increases IGF-I expression in the growth plate [34] and growth-suppressive doses of dexamethasone given to rabbits actually increases GH-receptor mRNA expression in the growth plate [35]. In vitro, glucocorticoid suppresses GH-receptor expression in cultured rat growth plate chondrocytes, while type I IGF receptor expression is not affected [31].

In addition to its direct action on the growth plate, glucocorticoid may also suppress longitudinal bone growth through an indirect action, involving other endocrine signals. In humans, glucocorticoid excess has been associated with reduced GH secretion in some studies [36], but not all [37]. The interpretation of these findings is complicated by the presence of the underlying disease requiring glucocorticoid treatment and by the suppressive effect of obesity per se on GH secretion. In humans, plasma IGF-I and IGF binding protein 3 levels have been found to be either normal [36] or increased [38].

Discontinuation of glucocorticoid treatment is followed by catch-up growth [8], which is caused, at least in part, by a mechanism intrinsic to the growth plate [7]. Catch-up growth may occur because the decreased cell proliferation during glucocorticoid treatment conserves the proliferative capacity of the chondrocytes, thus slowing growth plate senescence. Following discontinuation of the glucocorticoid treatment, the growth plates are less senescent than normal, and hence show a greater growth rate and grow for a longer time than expected for age, resulting in catch-up growth [8]. Despite catch-up growth, prolonged glucocorticoid administration in children can result in some residual permanent growth deficit.

\section{Thyroid Hormone}

Thyroid hormone is necessary for normal skeletal growth and maturation. Hypothyroidism slows longitudinal bone growth and endochondral ossification, while hyperthyroidism accelerates both processes [39, 40]. In hypothyroid animals, there is a decrease in the heights of the proliferative and hypertrophic zones, and a decrease in chondrocyte proliferation, chondrocyte hypertrophy, and vascular/bone cell invasion [41]. In addition, the normal columnar organization of the growth plate is disrupted [41].

Some of the skeletal effects of thyroid hormone appear to be due to a direct action on the growth plate. In fetal mouse tibia organ culture, thyroid hormone promotes longitudinal growth with the largest effect seen in the hypertrophic zone [42]. In cell culture, thyroid hormone stimulates hypertrophic differentiation, but often diminishes proliferation [43]. Local conversion of $T_{4}$ to $T_{3}$ by thyroid hormone deiodinase 2 in the growth plate may contribute to local effects [42].

Growth plate chondrocytes express thyroid hormone receptor (TR) isoforms TR- $\alpha_{1}, \alpha_{2}$, and $\beta_{1}$ [44]. Knocking out TR- $\beta$ isoforms in mice has little effect on the skeleton. In contrast, ablation of TR- $\alpha$ impairs longitudinal bone growth and endochondral ossification, effects that resemble hypothyroidism [45]. In humans, one family with homozygous deletion of TR- $\beta$ showed epiphyseal stippling and some delayed skeletal maturation but normal growth, suggesting that TR- $\beta$ mediate some of the effects of thyroid hormone on human skeletal development [46]. Thus, deletion of TR- $\beta$ affects skeletal development in humans, but has little effect in mice. Most cases of thyroid hormone resistance in humans are caused by dominant-negative mutations of the TR- $\beta$ gene that may affect TR- $\alpha$ function as well, and show variable skeletal effects [46].

In addition to its local action on the growth plate, thyroid hormone may have indirect effects on the growth plate, mediated by GH and IGF-I. In hypothyroid humans and mice, GH and IGF-I levels are reduced [47]. Replacing GH in hypothyroid rats, or in mice lacking TR$\alpha$, improves longitudinal bone growth. However, GH does not normalize growth plate endochondral ossification or morphology [47].

\section{Estrogen}

Premature estrogen exposure, as in precocious puberty, accelerates skeletal maturation, thus causing premature epiphyseal fusion and decreased final height. Conversely, lack of estrogen, as in hypogonadism, results in delayed fusion and tall stature. The role of estrogen in skeletal maturation and epiphyseal fusion was verified by the discovery of an estrogen-resistant man with a homozygous null mutation in the estrogen receptor- $\alpha(E R-\alpha)$ gene [48], and the detection of adults and children of both sexes with estrogen deficiency, as a consequence of mutations in the aromatase gene [49]. These patients exhibited normal growth until puberty, but failed to undergo epiphyseal fusion during puberty. Decelerating linear growth persisted into adulthood, resulting in tall stature. Thus, estrogen signaling through ER- $\alpha$ is crucial for normal skeletal maturation and epiphyseal fusion. These findings 
suggest that the final height of children might be increased by therapy with aromatase inhibitors [50] or antiestrogens [51]. Selective ER modulators could serve either as estrogen agonists or antagonists at the growth plate [52, 53].

Indirect evidence suggests that epiphyseal fusion occurs when the proliferative capacity of the growth plate chondrocytes is exhausted [9] and that estrogen acts by advancing growth plate senescence, causing earlier proliferative exhaustion, and thus earlier fusion [9]. This concept would explain why estrogen exposure does not induce fusion rapidly, but often must act for years before fusion occurs, particularly in young children.

During puberty, sex steroids induce a pubertal growth spurt. This growth acceleration may be primarily induced by estrogen since a near-normal growth spurt occurs in patients with androgen insensitivity [54], whereas little or no growth spurt appears to occur in patients with aromatase deficiency [55]. In addition, low-dose estrogen treatment can accelerate growth in both prepubertal boys and girls [56], and the accelerated growth in patients with familial male-limited precocious puberty is curtailed by the administration of an aromatase inhibitor [57]. The pubertal growth spurt also has a better temporal correlation with the increase in estrogen levels than with the increase in androgen levels [58]. Much of the growth acceleration appears to be mediated by estrogen-induced stimulation of the GH-IGF-I axis [55].

In addition to its effect on the GH-IGF-growth plate axis, estrogen also may act directly on the growth plate. Three lines of evidence support this hypothesis. First, ER$\alpha$ and $-\beta$ are expressed in growth plates cartilage [59]. Second, estrogen inhibits longitudinal bone growth of hypophysectomized and castrated female rats [60]. Third, human growth plate chondrocytes placed in primary culture reportedly respond to estrogen stimulation [61].

Gunther et al. [51] were able to inhibit estrogen-induced bone maturation using ICI 182,780, a pure antiestrogen, thus suggesting that estrogen acts to advance bone maturation, at least in part, through a classical ER.

The effects of estrogen on the growth plate differ markedly in mice and humans. First, mice, like most mammals studied, lack a pubertal growth spurt. In mice, estrogen does not stimulate longitudinal bone growth, but rather inhibits growth, an effect seen only at high doses in humans. Second, mice do not undergo epiphyseal fusion at the time of sexual maturation. Estrogen may promote fusion in mice, but only at supraphysiological concentrations. Third, in mice, the effects of estrogen on the growth plate appear to be mediated primarily by ER- $\beta$ rather than ER- $\alpha$. Female mice lacking ER- $\beta$ have slightly longer femurs than wild-type females [62]. In contrast, female mice lacking ER- $\alpha$ show decreased longitudinal bone growth and earlier epiphyseal fusion, perhaps because the increased levels of circulating estrogen in these mice act through ER- $\beta$ to accelerate epiphyseal fusion. Female mice lacking both ER- $\alpha$ and ER- $\beta$ have slightly elevated circulating estrogen, but do not exhibit accelerated epiphyseal fusion [63].

\section{Androgen}

Androgen also contributes to the pubertal growth spurt. Some of this effect is probably due to aromatization of androgens to estrogens in various peripheral tissues, including adipose tissue. Aromatase, the enzyme that converts androgens to estrogens, is expressed in growth plate cartilage [64], suggesting that some of the effects of androgen may be due to local conversion into estrogen. However, androgen per se, without conversion to estrogen, also appears to stimulate longitudinal bone growth. In boys, dihydrotestosterone, a nonaromatizable androgen, can accelerate linear growth [65]. This effect is not associated with increased circulating GH or IGF-I [65]. Similarly, testosterone stimulates growth in the absence of GH in hypophysectomized and castrated rats $[60,66]$.

These GH-independent effects of androgen may be due to a direct action of androgen on growth plate chondrocytes. Androgen receptor expression has been detected in rat [67] and human growth plate cartilage [59, 68]. Local administration of testosterone reportedly increases unilateral rat tibial epiphyseal growth plate width [69]. Furthermore, in vitro, dihydrotestosterone can stimulate proliferation and proteoglycan synthesis in growth plate chondrocytes [70]. Similarly, testosterone, and to a lesser extent, dihydrotestosterone stimulates chondrocyte proliferation in the mouse mandibular condyle, an organ culture model of endochondral ossification [71]. These local effects may be mediated, in part, by increased local IGFI expression [70, 71].

\section{Vitamin D}

In growing mammals, vitamin D deficiency produces a constellation of skeletal abnormalities known as rickets. The width of the hypertrophic zone of the growth plate is increased and mineralization is defective [72]. 


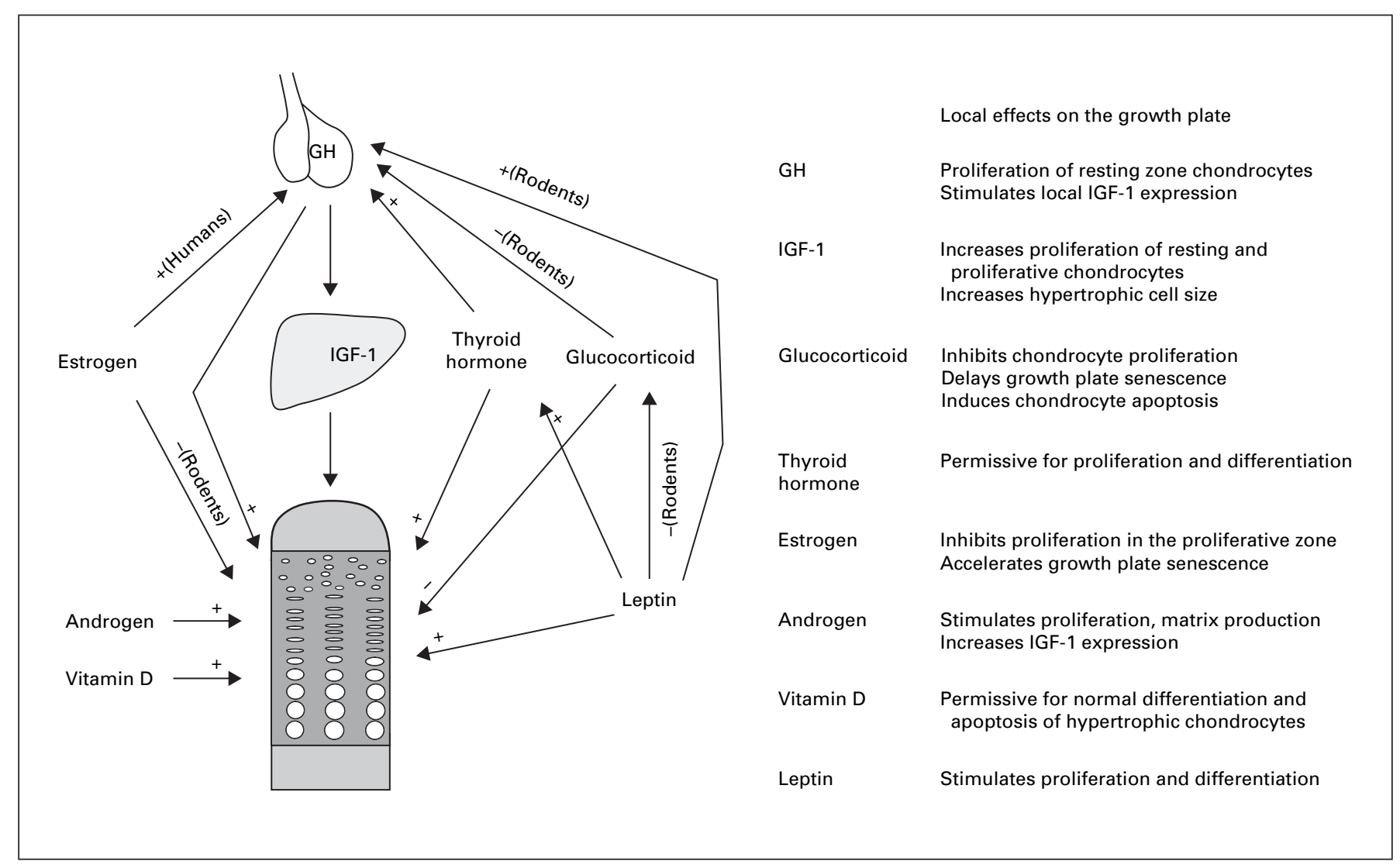

Fig. 2. Endocrine signals that regulates longitudinal bone growth. Arrows indicate direct action on the growth plate and indirect action by modulating other endocrine signals. + = Stimulatory effect; $-=$ inhibitory effect.

Similar effects occur in mice lacking the vitamin D receptor. In these mice there is decreased apoptosis of hypertrophic chondrocytes at the metaphyseal ends of the columns and delayed invasion by blood vessels and bone cells [73]. Rickets also occurs in hypophosphatemic mice and humans, suggesting that the decreased extracellular phosphate, which occurs in vitamin D deficiency, may play a key role in rickets. Indeed, a mineral-enriched diet can normalize the growth plates of vitamin D-deficient and vitamin D-resistant animals [74, 75]. Thus the growth plate effects of vitamin D may be mediated primarily through the vitamin $\mathrm{D}$ receptor expressed in intestinal epithelial cells, leading to increased calcium and phosphate absorption from the intestinal lumen.

Vitamin D metabolites, however, may also act directly on the growth plate. 24,25-dihydroxyvitamin $\mathrm{D}_{3}$ injected directly into rachitic chick growth plates resulted in healing [76]. In vitro, 24,25-dihydroxyvitamin $\mathrm{D}_{3}$ stimulates differentiation but decreases proliferation in resting zone cells, while 1,25-dihydroxyvitamin $\mathrm{D}_{3}$ decreases proliferation in resting and proliferative zones [77]. These effects appear to be mediated by a signal transduction pathway in chondrocytes involving cell surface receptors, phospholipases, prostaglandins, and the mitogen-activated protein kinase cascade [78]. Local conversion of vitamin D metabolites also occurs in rat costochondral chondrocytes by $1 \alpha$-hydroxylase and 24 -hydroxylase [79]. The physiological role of local vitamin D action on the growth plate remains unclear.

\section{Leptin}

Leptin, a protein secreted primarily by white adipose tissue, regulates food intake and body weight. Because circulating leptin levels are increased in obesity, it has been hypothesized that leptin might contribute to the ro- 
bust linear growth that occurs in obese children, despite low GH levels after craniopharyngioma surgery, and in idiopathic obesity [80]. Consistent with this hypothesis, leptin deficiency in mice impairs longitudinal bone growth, while treatment of these mice with leptin injections increased bone growth [81]. In contrast, in the few humans described with leptin deficiency or leptin-receptor deficiency, skeletal growth appeared grossly normal $[82,83]$. With in vivo studies, it is difficult to distinguish between leptin's direct effect on bone from its other systemic effects on nutritional balance, the GH-IGF axis, and circulating glucocorticoid levels. In organ cultures of mandibular condyle, a model of endochondral ossification, chondrocytes were found to contain specific binding sites for leptin [84], and leptin, at high concentrations, was found to stimulate chondrocyte proliferation and differentiation as well as IGF-I-receptor expression. Passive immunization of IGF-I abolished the effects of leptin on cell proliferation and differentiation [84]. The presence of the leptin receptor was also reported in primary cell culture of rabbit chondrocytes [85]. Taken together, these lines of evidence suggest that leptin may have a direct effect on chondrocytes in addition to its indirect effects, exerted through its ability to regulate appetite, energy metabolism, and endocrine systems. Leptin appears to affect bone density in mice by a mechanism involving the sympathetic nervous system [86]. Whether leptin can regulate longitudinal bone growth by a similar mechanism is not known.

\section{Conclusions}

Longitudinal bone growth at the growth plate is governed by a complex network of endocrine signals. Most of these signals regulate growth plate function by acting locally on growth plate chondrocytes and also indirectly by modulating other endocrine signals in the network (fig. 2). Some of the local effects of hormones are mediated by changes in paracrine factors that control chondrocyte proliferation and differentiation.

Our improved understanding in this field has provided insight into the molecular genetic causes of human growth failure. For example, human mutations affecting the $\mathrm{GH}-$ IGF-I system at many different levels have recently been shown to cause short stature, including mutations in genes encoding the GH-releasing hormone receptor [87], GH [88], STAT5b [10], IGF-I [13], acid labile subunit [89], and IGF-I receptor [14]. Molecular genetic defects affecting other endocrine regulators of growth also can cause growth plate dysfunction and short stature but often in conjunction with dysfunction of other tissues and organs, for example, mutations involving TR- $\beta$ [46].

New experimental approaches, including tissue-specific gene targeting, microarray analysis, and linkage studies exploiting the full sequence of the human and mouse genomes promise to accelerate progress in understanding these regulatory systems. These advances will lead to improved understanding of human skeletal growth disorders and are likely to yield new therapeutic approaches.

\section{References}

1 Kember NF: Cell population kinetics of bone growth: the first ten years of autoradiographic studies with tritiated thymidine. Clin Orthop 1971;76:213-230.

\2 Abad V, Meyers JL, Weise M, Gafni RI, Barnes KM, Nilsson O, Bacher JD, Baron J: The role of the resting zone in growth plate chondrogenesis. Endocrinology 2002;143:1851-1857.

-3 Hunziker EB: Mechanism of longitudinal bone growth and its regulation by growth plate chondrocytes. Microsc Res Tech 1994;28:505519.

4 Gerber HP, Vu TH, Ryan AM, Kowalski J, Werb Z, Ferrara N: VEGF couples hypertrophic cartilage remodeling, ossification and angiogenesis during endochondral bone formation. Nat Med 1999;5:623-628.

5 Farnum CE, Wilsman NJ: Cellular turnover at the chondro-osseous junction of growth plate cartilage: analysis by serial sections at the light microscopical level. J Orthop Res 1989;7:654666.
6 Stevens DG, Boyer MI, Bowen CV: Transplantation of epiphyseal plate allografts between animals of different ages. J Pediatr Orthop 1999; 19:398-403.

7 Baron J, Klein KO, Colli MJ, Yanovski JA, Novosad JA, Bacher JD, Cutler GB Jr: Catchup growth after glucocorticoid excess: a mechanism intrinsic to the growth plate. Endocrinology 1994;135:1367-1371.

8 Gafni RI, Weise M, Robrecht DT, Meyers JL, Barnes KM, De Levi S, Baron J: Catch-up growth is associated with delayed senescence of the growth plate in rabbits. Pediatr Res 2001;50:618-623.

-9 Weise M, De-Levi S, Barnes KM, Gafni RI, Abad V, Baron J: Effects of estrogen on growth plate senescence and epiphyseal fusion. Proc Natl Acad Sci USA 2001;98:6871-6876.
10 Kofoed EM, Hwa V, Little B, Woods KA, Buckway CK, Tsubaki J, Pratt KL, Bezrodnik L, Jasper H, Tepper A, Heinrich JJ, Rosenfeld RG: Growth hormone insensitivity associated with a STAT5b mutation. N Engl J Med 2003; 349:1139-1147.

11 Rosenfeld RG, Rosenbloom AL, GuevaraAguirre J: Growth hormone $(\mathrm{GH})$ insensitivity due to primary GH receptor deficiency. Endocr Rev 1994;15:369-390.

12 Wit JM, Kamp GA, Rikken B: Spontaneous growth and response to growth hormone treatment in children with growth hormone deficiency and idiopathic short stature. Pediatr Res 1996;39:295-302.

13 Woods KA, Camacho-Hubner C, Savage MO, Clark AJ: Intrauterine growth retardation and postnatal growth failure associated with deletion of the insulin-like growth factor I gene. N Engl J Med 1996;335:1363-1367. 
14 Abuzzahab MJ, Schneider A, Goddard A, Grigorescu F, Lautier C, Keller E, Kiess W, Klammt J, Kratzsch J, Osgood D, Pfaffle R, Raile K, Seidel B, Smith RJ, Chernausek SD: IGF-I receptor mutations resulting in intrauterine and postnatal growth retardation. $\mathrm{N}$ Engl J Med 2003;349:2211-2222.

$\checkmark 15$ Zhou Y, Xu BC, Maheshwari HG, He L, Reed M, Lozykowski M, Okada S, Cataldo L, Coschigamo K, Wagner TE, Baumann G, Kopchick JJ: A mammalian model for Laron syndrome produced by targeted disruption of the mouse growth hormone receptor/binding protein gene (the Laron mouse). Proc Natl Acad Sci USA 1997;94:13215-13220.

-16 Baker J, Liu JP, Robertson EJ, Efstratiadis A: Role of insulin-like growth factors in embryonic and postnatal growth. Cell 1993;75:73-82.

17 Daughaday WH, Hall K, Raben MS, Salmon WD Jr, van den Brande JL, van Wyk JJ: Somatomedin: proposed designation for sulphation factor. Nature 1972;235:107.

18 Butler AA, LeRoith D: Minireview: tissue-specific versus generalized gene targeting of the igf 1 and igflr genes and their roles in insulinlike growth factor physiology. Endocrinology 2001;142:1685-1688.

19 Yakar S, Rosen CJ, Beamer WG, Ackert-Bicknell CL, Wu Y, Liu JL, Ooi GT, Setser J, Frystyk J, Boisclair YR, LeRoith D: Circulating levels of IGF-1 directly regulate bone growth and density. J Clin Invest 2002;110:771-781.

-20 Guevara-Aguirre J, Rosenbloom AL, Vasconez O, Martinez V, Gargosky SE, Allen L, Rosenfeld RG: Two-year treatment of growth hormone $(\mathrm{GH})$ receptor deficiency with recombinant insulin-like growth factor I in 22 children: comparison of two dosage levels and to GH-treated GH deficiency. J Clin Endocrinol Metab 1997;82:629-633.

21 Sims NA, Clement-Lacroix P, Da Ponte F, Bouali Y, Binart N, Moriggl R, Goffin V, Coschigano K, Gaillard-Kelly M, Kopchick J, Baron R, Kelly PA: Bone homeostasis in growth hormone receptor-null mice is restored by IGF-I but independent of Stat5. J Clin Invest 2000;106:1095-1103.

22 Isaksson OG, Jansson JO, Gause IA: Growth hormone stimulates longitudinal bone growth directly. Science 1982;216:1237-1239.

- 23 Isgaard J, Moller C, Isaksson OG, Nilsson A, Mathews LS, Norstedt G: Regulation of insulin-like growth factor messenger ribonucleic acid in rat growth plate by growth hormone. Endocrinology 1988;122:1515-1520.

-24 Schlechter NL, Russell SM, Spencer EM, Nicoll CS: Evidence suggesting that the direct growth-promoting effect of growth hormone on cartilage in vivo is mediated by local production of somatomedin. Proc Natl Acad Sci USA 1986;83:7932-7934.

- 25 Ohlsson C, Nilsson A, Isaksson O, Lindahl A: Growth hormone induces multiplication of the slowly cycling germinal cells of the rat tibial growth plate. Proc Natl Acad Sci USA 1992; 89:9826-9830.
26 Isaksson OG, Lindahl A, Nilsson A, Isgaard J: Mechanism of the stimulatory effect of growth hormone on longitudinal bone growth. Endocr Rev 1987;8:426-438.

27 Hunziker EB, Wagner J, Zapf J: Differential effects of insulin-like growth factor I and growth hormone on developmental stages of rat growth plate chondrocytes in vivo. J Clin Invest 1994;93:1078-1086.

28 Wang J, Zhou J, Bondy CA: Igf1 promotes longitudinal bone growth by insulin-like actions augmenting chondrocyte hypertrophy. FASEB J 1999;13:1985-1990.

-29 Silvestrini G, Ballanti P, Patacchioli FR, Mocetti P, Di Grezia R, Wedard BM, Angelucci L, Bonucci E: Evaluation of apoptosis and the glucocorticoid receptor in the cartilage growth plate and metaphyseal bone cells of rats after high-dose treatment with corticosterone. Bone 2000;26:33-42.

30 Chrysis D, Ritzen EM, Savendahl L: Growth retardation induced by dexamethasone is associated with increased apoptosis of the growth plate chondrocytes. J Endocrinol 2003;176: 331-337.

- 31 Jux C, Leiber K, Hugel U, Blum W, Ohlsson C, Klaus G, Mehls O: Dexamethasone impairs growth hormone $(\mathrm{GH})$-stimulated growth by suppression of local insulin-like growth factor (IGF)-I production and expression of GH- and IGF-I-receptor in cultured rat chondrocytes. Endocrinology 1998;139:3296-3305.

32 Baron J, Huang Z, Oerter KE, Bacher JD, Cutler GB Jr: Dexamethasone acts locally to inhibit longitudinal bone growth in rabbits. Am J Physiol 1992;263:489-492.

33 Smink JJ, Gresnigt MG, Hamers N, Koedam JA, Berger R, van Buul-Offers SC: Short-term glucocorticoid treatment of prepubertal mice decreases growth and IGF-I expression in the growth plate. J Endocrinol 2003;177:381-388.

34 Smink JJ, Koster JG, Gresnigt MG, Rooman R, Koedam JA, van Buul-Offers SC: IGF and IGF-binding protein expression in the growth plate of normal, dexamethasone-treated and human IGF-II transgenic mice. J Endocrinol 2002;175:143-153.

35 Heinrichs C, Yanovski JA, Roth AH, Yu YM, Domene HM, Yano K, Cutler GB Jr, Baron J: Dexamethasone increases growth hormone receptor messenger ribonucleic acid levels in liver and growth plate. Endocrinology 1994;135: 1113-1118.

-36 Magiakou MA, Mastorakos G, Gomez MT, Rose SR, Chrousos GP: Suppressed spontaneous and stimulated growth hormone secretion in patients with Cushing's disease before and after surgical cure. J Clin Endocrinol Metab 1994;78:131-137.

- 37 Crowley S, Hindmarsh PC, Matthews DR, Brook CG: Growth and the growth hormone axis in prepubertal children with asthma. J Pediatr 1995;126:297-303.

38 Borges MH, Pinto AC, DiNinno FB, Camacho-Hubner C, Grossman A, Kater CE, Lengyel AM: IGF-I levels rise and GH responses to GHRH decrease during long-term prednisone treatment in man. J Endocrinol Invest 1999; 22:12-17.
39 Buckler JM, Willgerodt H, Keller E: Growth in thyrotoxicosis. Arch Dis Child 1986;61:464471.

40 Leger J, Czernichow P: Congenital hypothyroidism: decreased growth velocity in the first weeks of life. Biol Neonate 1989;55:218-223.

41 Stevens DA, Hasserjian RP, Robson H, Siebler T, Shalet SM, Williams GR: Thyroid hormones regulate hypertrophic chondrocyte differentiation and expression of parathyroid hormone-related peptide and its receptor during endochondral bone formation. J Bone Miner Res 2000; 15:2431-2442.

42 Miura M, Tanaka K, Komatsu Y, Suda M, Yasoda A, Sakuma Y, Ozasa A, Nakao K: Thyroid hormones promote chondrocyte differentiation in mouse ATDC5 cells and stimulate endochondral ossification in fetal mouse tibias through iodothyronine deiodinases in the growth plate. J Bone Miner Res 2002; 17:443454.

43 Robson H, Siebler T, Stevens DA, Shalet SM, Williams GR: Thyroid hormone acts directly on growth plate chondrocytes to promote hypertrophic differentiation and inhibit clonal expansion and cell proliferation. Endocrinology 2000;141:3887-3897.

44 Ballock R, Mita BC, Zhou X, Chen DH, Mink LM: Expression of thyroid hormone receptor isoforms in rat growth plate cartilage in vivo. $\mathrm{J}$ Bone Miner Res 1999;14:1550-1556.

$\checkmark 45$ Gauthier K, Chassande O, Plateroti M, Roux JP, Legrand C, Pain B, Rousset B, Weiss R, Trouillas J, Samarut J: Different functions for the thyroid hormone receptors TRalpha and TRbeta in the control of thyroid hormone production and post-natal development. EMBO J 1999; 18:623-631.

46 Takeda K, Sakurai A, Degroot LJ, Refetoff S: Recessive inheritance of thyroid hormone resistance caused by complete deletion of the protein-coding region of the thyroid hormone receptor-beta gene. J Clin Endocrinol Metab 1992;74:49-55.

47 Kindblom JM, Gothe S, Forrest D, Tornell J, Tornell J, Vennstrom B, Ohlsson C: GH substitution reverses the growth phenotype but not the defective ossification in thyroid hormone receptor alpha 1-/-beta-/- mice. J Endocrinol 2001;171:15-22.

48 Smith EP, Boyd J, Frank GR, Takahashi H, Cohen RM, Specker B, Williams TC, Lubahn DB, Korach KS: Estrogen resistance caused by a mutation in the estrogen-receptor gene in a man [see comments] [published erratum appears in N Engl J Med 1995;332:131]. N Engl J Med 1994;331:1056-1061.

- 49 Morishima A, Grumbach MM, Simpson ER, Fisher C, Qin K: Aromatase deficiency in male and female siblings caused by a novel mutation and the physiological role of estrogens. Clin Endocrinol Metab 1995;80:3689-3698.

-50 Wickman S, Sipila I, Ankarberg-Lindgren C, Norjavaara E, Dunkel L: A specific aromatase inhibitor and potential increase in adult height in boys with delayed puberty: a randomised controlled trial. Lancet 2001;357:1743-1748. 
-51 Gunther DF, Calikoglu AS, Underwood LE: The effects of the estrogen receptor blocker, Faslodex (ICI 182,780), on estrogen-accelerated bone maturation in mice. Pediatr Res 1999;46:269-273.

- 52 Eugster EA, Rubin SD, Reiter EO, Plourde P, Jou HC, Pescovitz OH: Tamoxifen treatment for precocious puberty in McCune-Albright syndrome: a multicenter trial. J Pediatr 2003; 143:60-66.

- 53 Nilsson O, Falk J, Ritzen EM, Baron J, Savendahl L: Raloxifene acts as an estrogen agonist on the rabbit growth plate. Endocrinology 2003;144:1481-1485.

-54 Zachmann M, Prader A, Sobel EH, Crigler JF Jr, Ritzen EM, Atares M, Ferrandez A: Pubertal growth in patients with androgen insensitivity: indirect evidence for the importance of estrogens in pubertal growth of girls. J Pediatr 1986;108:694-697.

-55 Grumbach MM: Estrogen, bone, growth and sex: a sea change in conventional wisdom. $\mathrm{J}$ Pediatr Endocrinol Metab 2000;13(suppl 6): 1439-1455.

56 Cutler GB Jr: The role of estrogen in bone growth and maturation during childhood and adolescence. J Steroid Biochem Mol Biol 1997; 61:141-144.

-57 Laue L, Kenigsberg D, Pescovitz OH, Hench KD, Barnes KM, Loriaux DL, Cutler GB Jr: Treatment of familial male precocious puberty with spironolactone and testolactone. N Engl J Med 1989;320:496-502.

- 58 Klein KO, Martha PM Jr, Blizzard RM, Herbst T, Rogol AD: A longitudinal assessment of hormonal and physical alterations during normal puberty in boys. II. Estrogen levels as determined by an ultrasensitive bioassay. J Clin Endocrinol Metab 1996;81:3203-3207.

- 59 Nilsson O, Chrysis D, Pajulo O, Boman A, Holst M, Rubinstein J, Martin RE, Savendahl L: Localization of estrogen receptors-alpha and -beta and androgen receptor in the human growth plate at different pubertal stages. J Endocrinol 2003; 177:319-326.

60 Jansson JO, Eden S, Isaksson O: Sites of action of testosterone and estradiol on longitudinal bone growth. Am J Physiol 1983;244:135140 .

61 Blanchard O, Tsagris L, Rappaport R, DuvalBeaupere G, Corvol M: Age-dependent responsiveness of rabbit and human cartilage cells to sex steroids in vitro. J Steroid Biochem Mol Biol 1991;40:711-716.

-62 Lindberg MK, Alatalo SL, Halleen JM, Mohan S, Gustafsson JA, Ohlsson C: Estrogen receptor specificity in the regulation of the skeleton in female mice. J Endocrinol 2001;171:229236.

-63 Chagin AS, Lindberg MK, Andersson N, Moverare S, Gustafsson JA, Savendahl L, Ohlsson C: Estrogen receptor-beta inhibits skeletal growth and has the capacity to mediate growth plate fusion in female mice. $\mathrm{J}$ Bone Miner Res 2004;19:72-77.

- 64 Oz OK, Millsaps R, Welch R, Birch J, Zerwekh JE: Expression of aromatase in the human growth plate. J Mol Endocrinol 2001;27:249_ 253.
65 Keenan BS, Richards GE, Ponder SW, Dallas JS, Nagamani M, Smith ER: Androgen-stimulated pubertal growth: the effects of testosterone and dihydrotestosterone on growth hormone and insulin-like growth factor-I in the treatment of short stature and delayed puberty. J Clin Endocrinol Metab 1993;76:996-1001.

66 Phillip M, Maor G, Assa S, Silbergeld A, Segev Y: Testosterone stimulates growth of tibial epiphyseal growth plate and insulin-like growth factor-1 receptor abundance in hypophysectomized and castrated rats. Endocrine 2001; 16: $1-6$.

67 van der Eerden BC, van Til NP, Brinkmann AO, Lowik CW, Wit JM, Karperien M: Gender differences in expression of androgen receptor in tibial growth plate and metaphyseal bone of the rat. Bone 2002;30:891-896.

68 Abu EO, Horner A, Kusec V, Triffitt JT, Compston JE: The localization of androgen receptors in human bone. J Clin Endocrinol Metab 1997;82:3493-3497.

-69 Ren SG, Malozowski S, Sanchez P, Sweet DE, Loriaux DL, Cassorla F: Direct administration of testosterone increases rat tibial epiphyseal growth plate width. Acta Endocrinol (Copenh) 1989;121:401-405.

70 Krohn K, Haffner D, Hugel U, Himmele R, Klaus G, Mehls O, Schaefer F: 1,25(OH)2D3 and dihydrotestosterone interact to regulate proliferation and differentiation of epiphyseal chondrocytes. Calcif Tissue Int 2003;73:400-410.

71 Maor G, Segev Y, Phillip M: Testosterone stimulates insulin-like growth factor-I and insulin-like growth factor-I-receptor gene expression in the mandibular condyle - a model of endochondral ossification. Endocrinology 1999;140:1901-1910.

72 Dean DD, Boyan BD, Schwart Z, Muniz OE, Carreno MR, Maeda S, Howell DS: Effect of 1alpha,25-dihydroxyvitamin D3 and 24R,25dihydroxyvitamin D3 on metalloproteinase activity and cell maturation in growth plate cartilage in vivo. Endocrine 2001;14:311-323.

73 Donohue MM, Demay MB: Rickets in VDR null mice is secondary to decreased apoptosis of hypertrophic chondrocytes. Endocrinology 2002;143:3691-3694.

-74 Amling M, Priemel M, Holzmann T, Chapin K, Rueger JM, Baron R, Demay MB: Rescue of the skeletal phenotype of vitamin D receptor-ablated mice in the setting of normal mineral ion homeostasis: formal histomorphometric and biomechanical analyses. Endocrinology 1999; 140:4982-4987.

75 Underwood JL, DeLuca HF: Vitamin D is not directly necessary for bone growth and mineralization. Am J Physiol 1984;246:E493-E498.

76 Lidor C, Atkin I, Ornoy A, Dekel S, Edelstein S: Healing of rachitic lesions in chicks by 24R,25dihydroxycholecalciferol administered locally into bone. J Bone Miner Res 1987;2:91-98.

77 Boyan BD, Sylvia VL, Dean DD, Del Toro F, Schwartz Z: Differential regulation of growth plate chondrocytes by 1alpha,25-(OH)2D 3 and 24R,25-(OH)2D3 involves cell-maturationspecific membrane-receptor-activated phospholipid metabolism. Crit Rev Oral Biol Med 2002;13:143-154.
78 Schwartz Z, Ehland H, Sylvia VL, Larsson D, Hardin RR, Bingham V, Lopez D, Dean DD, Boyan BD: 1alpha,25-dihydroxyvitamin $\mathrm{D}(3)$ and 24R,25-dihydroxyvitamin D(3) modulate growth plate chondrocyte physiology via protein kinase C-dependent phosphorylation of extracellular signal-regulated kinase 1/2 mitogen-activated protein kinase. Endocrinology 2002;143:2775-2786.

79 Schwartz Z, Pedrozo HA, Sylvia VL, Gomez R, Dean DD, Boyan BD: 1alpha,25-(OH)2D3 regulates 25-hydroxyvitamin D3 24R-hydroxylase activity in growth zone costochondral growth plate chondrocytes via protein kinase C. Calcif Tissue Int 2001;69:365-372.

80 Vignolo M, Naselli A, Di Battista E, Mostert M, Aicardi G: Growth and development in simple obesity. Eur J Pediatr 1988;147:242244.

81 Steppan CM, Crawford DT, Chidsey-Frink $\mathrm{KL}, \mathrm{Ke} \mathrm{H}$, Swick AG: Leptin is a potent stimulator of bone growth in ob/ob mice. Regul Pept 2000;92:73-78.

- 82 Clement K, Vaisse C, Lahlou N, Cabrol S, Pelloux V, Cassuto D, Gourmelen M, Dina C, Chambaz J, Lacorte JM, Basdevant A, Bougneres P, Lebouc Y, Froguel P, Guy-Grand B: A mutation in the human leptin receptor gene causes obesity and pituitary dysfunction. Nature 1998;392:398-401.

83 Ozata M, Ozdemir IC, Licinio J: Human leptin deficiency caused by a missense mutation: multiple endocrine defects, decreased sympathetic tone, and immune system dysfunction indicate new targets for leptin action, greater central than peripheral resistance to the effects of leptin, and spontaneous correction of leptinmediated defects. J Clin Endocrinol Metab 1999;84:3686-3695.

84 Maor G, Rochwerger M, Segev Y, Phillip M: Leptin acts as a growth factor on the chondrocytes of skeletal growth centers. J Bone Miner Res 2002;17:1034-1043.

85 Nakajima R, Inada H, Koike T, Yamano T: Effects of leptin to cultured growth plate chondrocytes. Horm Res 2003;60:91-98.

-86 Elefteriou F, Ahn JD, Takeda S, Starbuck M, Yang X, Liu X, Kondo H, Richards WG, Bannon TW, Noda M, Clement K, Vaisse C, Karsenty G: Leptin regulation of bone resorption by the sympathetic nervous system and CART. Nature 2005;434:514-520.

87 Wajnrajch MP, Gertner JM, Harbison MD, Chua SC Jr, Leibel RL: Nonsense mutation in the human growth hormone-releasing hormone receptor causes growth failure analogous to the little (lit) mouse. Nat Genet 1996;12: $88-90$.

88 Wagner JK, Eble A, Hindmarsh PC, Mullis PE: Prevalence of human GH-1 gene alterations in patients with isolated growth hormone deficiency. Pediatr Res 1998;43:105-110.

89 Domene HM, Bengolea SV, Martinez AS, Ropelato MG, Pennisi P, Scaglia P, Heinrich JJ, Jasper HG: Deficiency of the circulating insulin-like growth factor system associated with inactivation of the acid-labile subunit gene. $\mathrm{N}$ Engl J Med 2004;350:570-577. 